Tohoku J. exp. Med., 1971, 104, 263-287

\title{
Abnormal Eustachian Valve
}

\author{
Gen Niwayama and Vibul V. Vadakan \\ Department of Pathology and Pediatrics, School of Medicine, \\ University of California, Los Angeles, California, and Depart- \\ ment of Pathology, Children's Hospital, State University of \\ New York at Buffalo, U.S.A.
}

Niwayama, G. and Vadakan, V.V. Abnormal Eustachian Valve. Tohoku J. exp. Med., 1971, 104 (3), 263-287 — Congenital anomalies of the Eustachian valve were found in 3 patients. In a 12 -year-old boy, the valve was abnormally enlarged and thickened, causing moderate constriction of the inferior vena cava orifice. A one-month-old infant exhibited aneurysmal dilatation in the midportion of the valve, combined with a right aortic arch and interventricular septal defect. A markedly enlarged, membranous Eustachian valve was present in a 2* month-old baby, with associated interventricular septal defect, transposition of the great vessels and bicuspid pulmonic valve. congenital anomaly; Eustachian valve

Ever since interatrial septal defects have been included among congenital heart diseases which can be helped by surgical repair (Bailey et al. 1953, Gross et al. 1953, Bjork et al. 1954), exact knowledge of the normal anatomy of the right atrium and the recognition of deviations from the normal formation of its valves are no longer matters of mere embryologic and morphologic interest, but are rather emerging as actual clinical problems. The Eustachian and Thebesian valves, at the entrance of the inferior vena cava and of the coronary sinus, respectively, are normally both the remnants of the right valve of the sinus venosus. The existence of a valve at the opening of the inferior vena cava into the right atrium was first described by Bartolommeo Eustachius in 1563. The first case of pathologic persistence of this structure was reported by Lindes in 1865 in a heart which also exhibited a single atrial cavity and structures, later interpreted by Yater (1929) as persistent right and left venous valves. Minor abnormal persistence of the valves of the sinus venosus, resulting in a larger than usual Eustachian valve, Thebesian valve or Chiari's network, were reviewed and classified by Yater in 1929. Doucette and Knoblich (1963) recognized four anatomic patterns of pathological persistence of the right valve of the sinus venosus. Lucas and Schmidt (1968) mentioned 15 cases in the literature and broadened the classification offered by Doucette and Knoblich (1963). This paper represents an attempt to review the 70 cases which the authors have been able to trace in the literature, with additional report of three cases from the Children's Hospital of Buffalo.

Received for publication, December 22, 1970.

Reprint request should be sent to Dr. Niwayama, Dspartment of Pathology, University of California, Los Angeles, California, 90024, U.S.A. 


\section{Case 1}

Maternal history: Unremarkable. Gestational period: full term, uncomplicated. Normal labor. Baby: vigorous and acyanotic. No resuscitation required. Birth weight: 8 pounds.

Medical history: Measles, German measles and pneumonia in early childhood. At the age of 7 years, a soft systolic heart murmur was detected by the family physician. However, this was not heard on subsequent examinations, according to the patient's mother. The patient remained in good physical health until 12 years of age. Two weeks prior to demise, he experienced an episode of cyanosis and light-headedness while wrestling. Because of the previous history of heart murmur, a medical clinic appointment was requested.

Physical examination: According to the residents note, there were no signs of symptoms characteristic of heart disease.

X-ray: Transverse diameter of chest: $28.6 \mathrm{~cm}$, heart: $13.4 \mathrm{~cm}$. Normal cardiac silhuette and lung fields.

Electrocardiogram: Severe left ventricular hypertrophy.

Clinical course: On the day following medical examination in the clinic, the child collapsed and died while running track at school.

Family history: Father died at ag 3 35, with the clinical diagnosis of acute myocarditis. A younger sibling has "rheumatic heart disease." Two other siblings are well. Three paternal uncles died of undefined cardiac diseases at early ages.

Autopsy findings: Very well developed, well nourished white male. The hronchomediastinal lymph nodes were moderately enlarged and slightly congested. There was marked congestion of the neck veins, liver, spleen and kidneys. The lungs were well expanded with somewhat emphysematous appearance.

Significant necropsy findings were limited to the heart, which was markedly enlarged, measuring $9.7 \mathrm{~cm} \times 11.5 \mathrm{~cm}$. The left ventricle and papillary muscles were markedly hypertrophied, the ventricular wall measuring $13-19 \mathrm{~mm}$, as compared with the right ventricle, $4-5 \mathrm{~mm}$ in thickness. The left atrium appeared slightly grayish-yellow. The right atrium was slightly dilated and the atrial wall slightly thickened. The Eustachian valve had a semilunar appearance and was abnormally large, measuring $2.4 \mathrm{~cm}$ at the margin, $2.1 \mathrm{~cm}$ in width and $2 \mathrm{~mm}$ in thickness. Its upper surface was smooth and regular. The undersurface revealed several fine band-like irregularities. The whole valve was firm, muscular and not fenestrated. The junction of the anterior inferior free margin with the septum was about $7 \mathrm{~mm}$ below the lower margin of the fossa ovalis and $1 \mathrm{~cm}$ above the commissure of the tricuspid cusps. The upper posterior junction of the valve was $9 \mathrm{~mm}$ above the upper margin of the fossa ovalis. Below the Eustachian valve, the coronary sinus and the Thebesian valve were normally located. The crista 


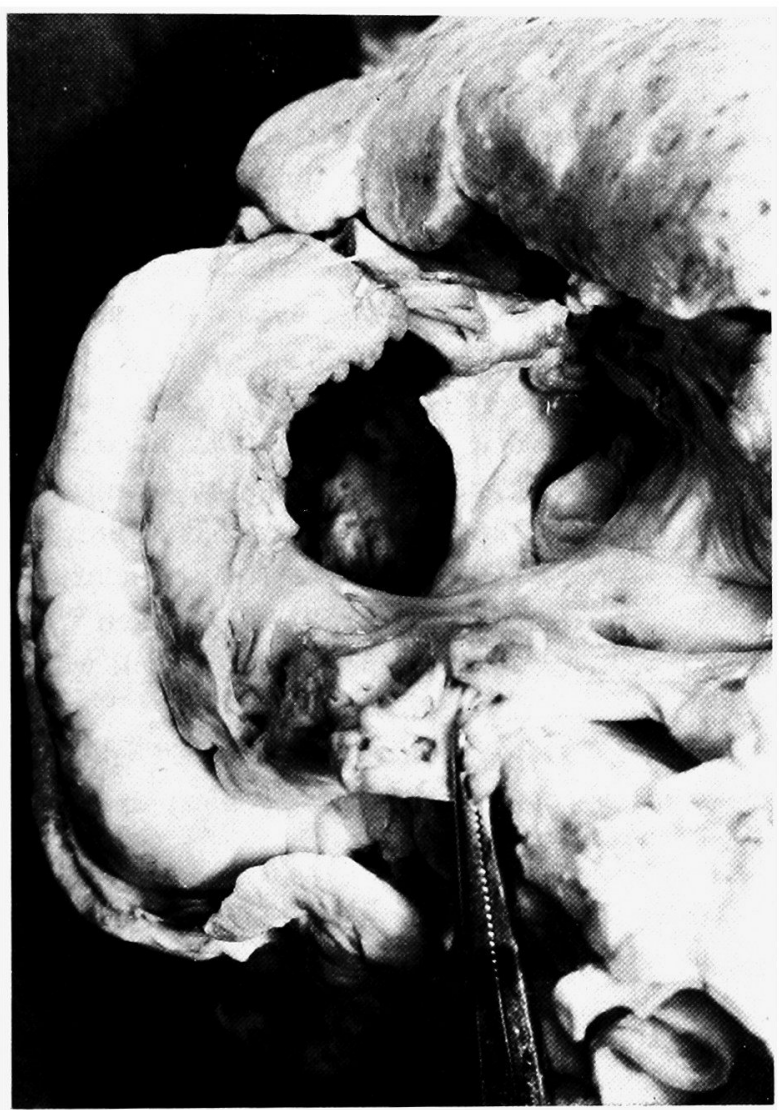

Fig. 1.

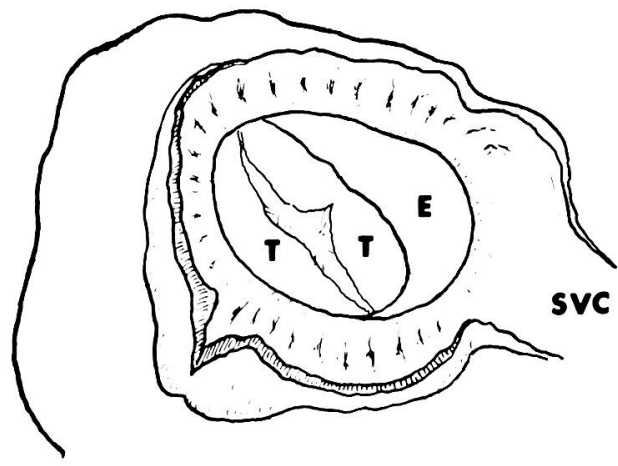

Fig. 2.

Figs. 1 and 2. Superior view of the right atrium (case 1) E: Eustachian valve. SVC: Superior vena cava. T: tricuspid valve. 
terminalis was prominent. The tuberculum Loweri was clearly recognizable.

The fibrous fossa ovalis measured $2.2 \mathrm{~cm} \times 2 \mathrm{~cm}$. The superior vena cava measured $4.2 \mathrm{~cm}$ in circumference at its entrance into the right atrium. The inferior vena cava was moderately dilated and measured $5.9 \mathrm{~cm}$ in circumference. The right atrium was partly divided by the anomalous Eustachian valve and the valve itself appeared to constrict the entrance of the inferior vena cava, causing marked congestion of the abdominal viscera. The heart valves were regular and measured: tricuspid $9.5 \mathrm{~cm}$, pulmonic $6.9 \mathrm{~cm}$, mitral $10.1 \mathrm{~cm}$ and aortic $5.9 \mathrm{~cm}$ in circumference.

Microscopic examination: Sections taken from the left ventricle revealed distinct hypertrophy of the cardiac musculature with microscopic appearance of severe chronic myocarditis. The finding was somewhat similar to that of an older stage of rheumatic lesions. Sections taken from the left atrium showed a moderate degree of endocardial fibrosis, which was considered secondary to severe myocardial damage to the left ventricle. Microscopic section taken from the Eustachian valve itself revealed normal cardiac muscle bundles which were continuous with the musculature of the right atrial wall.

The lungs showed marked congestion. There was slight to moderate mural thickening, especially of the media in small arterioles; spleen and kidneys were markedly congested.

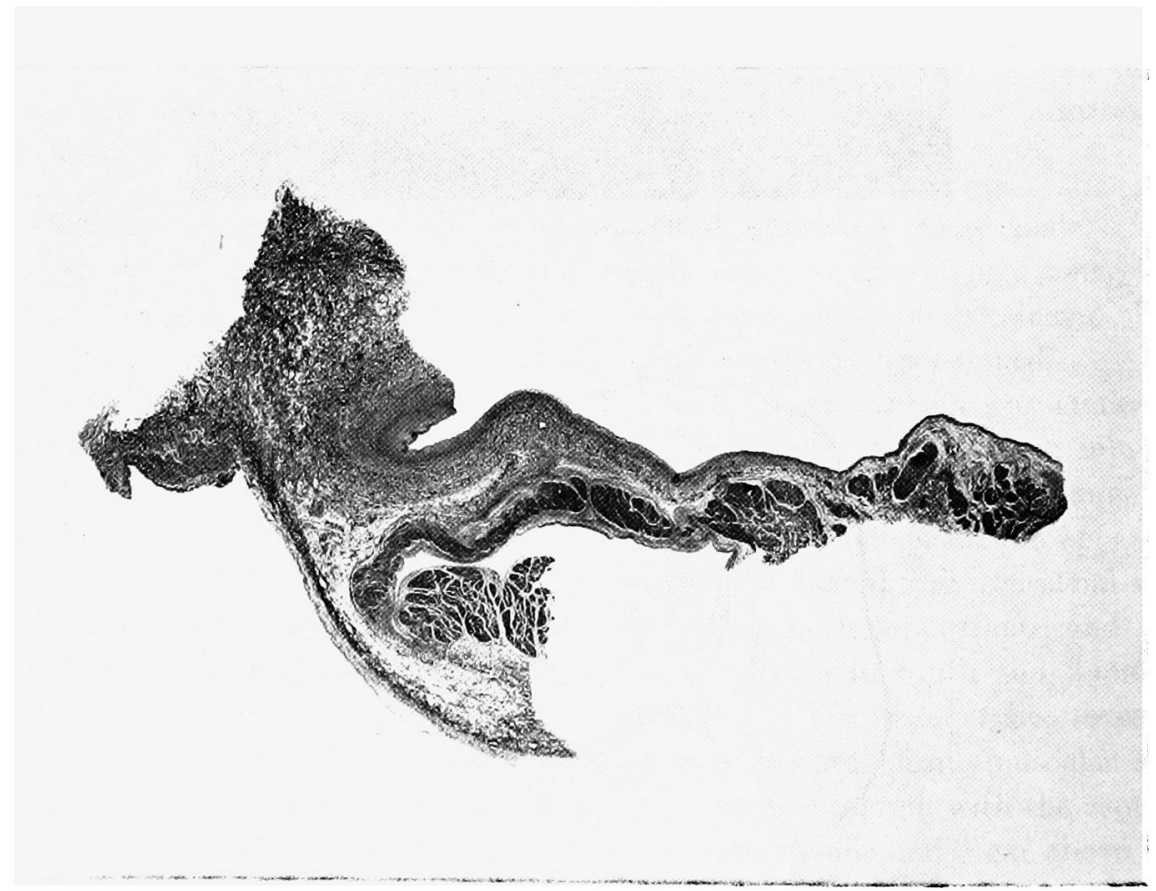

Fig. 3. Microphotograph of the Eustachian valve. (H.E. stain) 


\section{CASE 2}

Maternal history: Pregnancy complicated by elevated blood pressure and pedal edema. Spontaneous vaginal delivery complicated by prolapsed cord. No immediate neonatal complication.

Medical history: A transient heart murmur, of unspecified nature, was noted on the second day of life. The child was discharged without further diagnostic evaluation. He returned at 6 days of age with cyanosis, grade III/VI systolic heart murmur, heard equally over the entire precordium, and hepatomegaly, palpable one fingerbreadth below the right costal margin. During hospitalization bilareral staphylococcal conjunctivitis was noted, which precluded definitive evaluation of his cardiac status. He was readmitted at 3 weeks of age with a history of cyanosis, dyspnea, poor feeding and one apneic episode requiring resuscitation.

Physical examination: Pulse 120, respiration 32, lethargic. Mild cyanosis. HEENT: normal. Lungs: normal. Heart: PMI left of anterior axillary line. Grade IV/VI systolic murmur best heard at fourth intercostal space, left sternal border. No hepatosplenomegaly.

Laboratory data: Hemoglobin $13.3 \%$. WBC 11,400. Urinalysis: within normal limits.

X-ray: Cardiothoracic ratio $5.8 \mathrm{~cm} / 9.1 \mathrm{~cm}$. Cardiac configuration unremarkable. Extensive pneumonic densities in upper halves of both lung fields and along right cardiac border.

Hospital course: The hospital stay was complicated by frequent cyanotic and apenic episodes requiring digitalization and use of antibiotics. Cardiac arrest occurred on the seventh day of hospitalization. Resuscitation was successful but endotracheal intubation with artificial ventilation was required. The child's condition deteriorated progressively and he expired at the age of 32 days.

At autopsy there were no significant findings in larynx, trachea and main bronchi. The pleural cavities were free of effusion. Both lungs were atelectatic. There was congestion of the neck veins, liver, spleen and kidneys.

The pericardial sac contained about $3 \mathrm{ml}$ of slightly bloodtinged fluid. The heart was markedly enlarged. The right ventricle was markedly dilated and hypertrophied, up to $6-7 \mathrm{~mm}$ in thickness. The atria were unremarkable. The foramen ovale appeared as a slit-like opening. A small interventricular septal defect was present beneath the posterior cusp of the aortic valve, $4-5 \mathrm{~mm}$ in diameter. The valves measure: tricuspid $3.7 \mathrm{~cm}$, pulmonic $2.6 \mathrm{~cm}$, mitral $3.4 \mathrm{~cm}$ and aortic $2.2 \mathrm{~cm}$ in circumference. The coronary arteries appeared normal. The pulmonary artery was of normal caliber. The aorta showed a right-sided arch. The ductus arteriosus was closed. The superior vena cava was normal. The inferior vena cava revealed an abnormally elongated Eustachian valve. This thin, membranous structure exhibited an area of aneurysmal dilatation in its mid- 


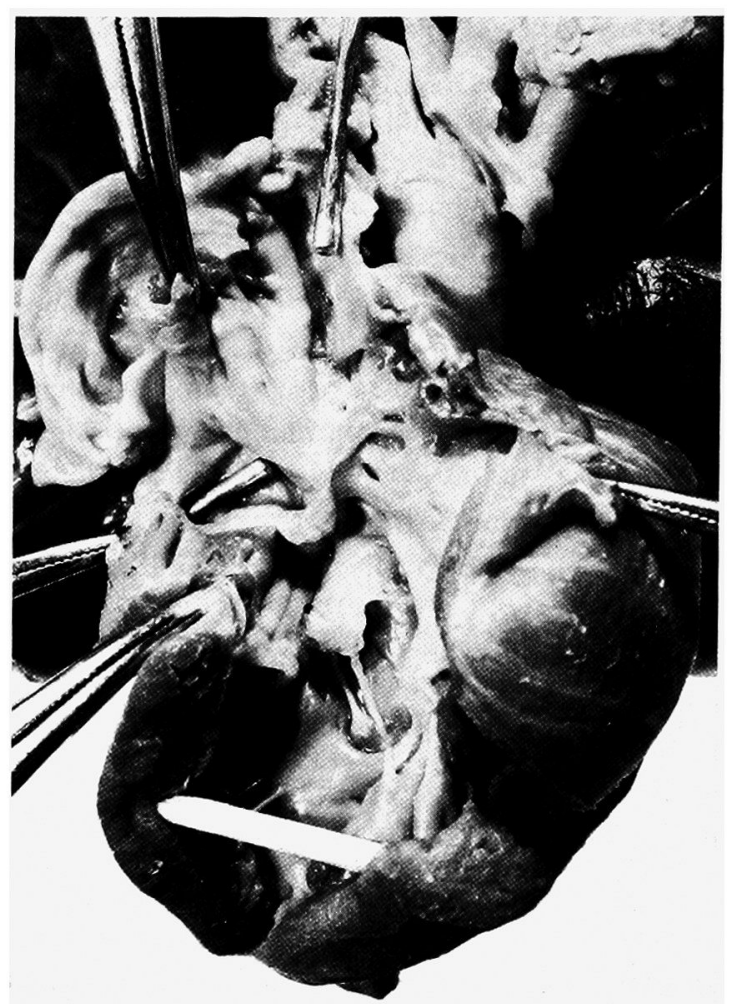

Fig. 4.

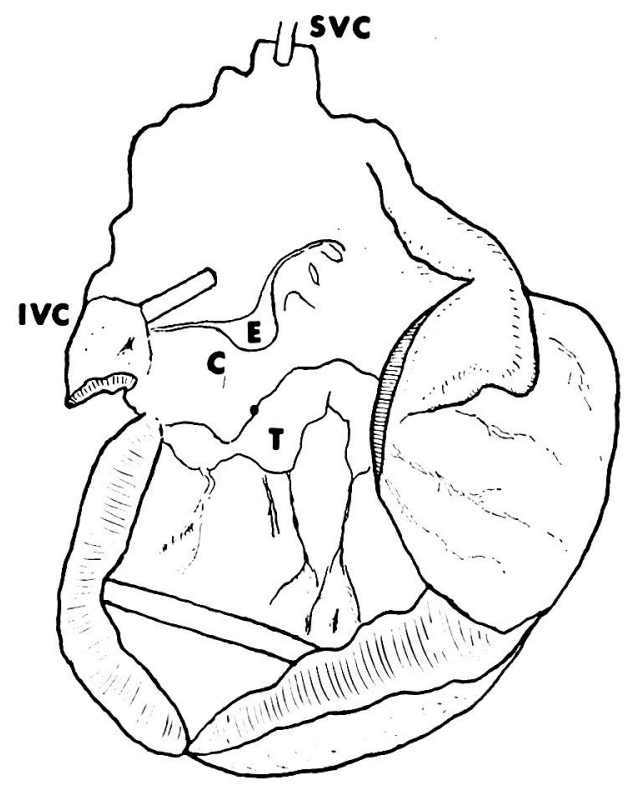

Fig. 5. 
portion. The coronary sinus and Thebesian valve were normal.

A small hemangioma was present on the septal cusp of the tricuspid valve.

Microscopic examination: Non-contributory.

\section{CASE 3}

The third patient is a male infant with multiple congenital cardiac anomalies who died at 9 months of age from thromboembolism to the left internal carotid artery.

Autopsy findings: Larynx, trachea, main bronchi and lungs were not remarkable except for small area of atelectasis in basal segment of left lower lobe. Pleural cavities were free of effusion.

The pericardial sac contained a small amount of clear amber tluid. The heart was enlarged, $5.7 \mathrm{~cm}$ in vertical and $5.6 \mathrm{~cm}$ in horizontal plane. The right ventricle was markedly dilated and hypertrophied, 7-9 mm in thickness, as against $3-6 \mathrm{~mm}$ of the left ventricular wall. The atria were not remarkable. A minute opening was present at the foramen ovale. There was a large interventricular septal defect, measuring $2 \mathrm{~cm}$ vertically and $1.3 \mathrm{~cm}$ horizontally in diameter. The upper edge of the defect was located $12 \mathrm{~mm}$ below the pulmonary valve. The tricuspid valve measured $4.5 \mathrm{~cm}$, mitral valve $4.2 \mathrm{~cm}$. The chordae tendineae of the anterior cusp of the mitral valve attached themselves to an area just beneath the crista supraventricularis of the right ventricle. Some of the chordae tendineae of the posterior cusp of the mitral valve showed similar adhesions to the right side of the right ventricular wall. The aorta arose from the right ventricle and measured $3.9 \mathrm{~cm}$ in circumference. Three aortic cusps and two coronary ostia were noted. Petechiae were seen on the adventitial layer of the ascending portion of the aorta. The pulmonary ostimum with its two cusps arose from the left ventricle and measured $2.4 \mathrm{~cm}$ in circumference. Probe patency was present of the ductus arteriosus. The left subclavian artery took its origin at a point proximal to the ductus arteriosus. The superior and inferior venae cavae emptied normally into the right atrium. The coronary sinus and Thebesian valve were unremarkable. Small recent thrombi were present at the lower margin of the interventricular septal defect and also on the posterior surface of the anterior cusp of the mitral vale.

The Eustachian valve was abnormally enlarged, measuring $11 \mathrm{~mm}$ at its greatest width. It was thin and membranous except for a small muscular portion on the side facing the interatrial septum.

Figs. 4 and 5. Right atrium and ventricle (Case 2). C: Coronary sinus. E: Eustachian valve. IVC: Inferior vena cava. SVC: Superior vena cava. T: Tricuspid valve. $\mathrm{A}$ dot between $\mathrm{C}$ and $\mathrm{T}$ indicates a small hemangioma of the tricuspid valve. 


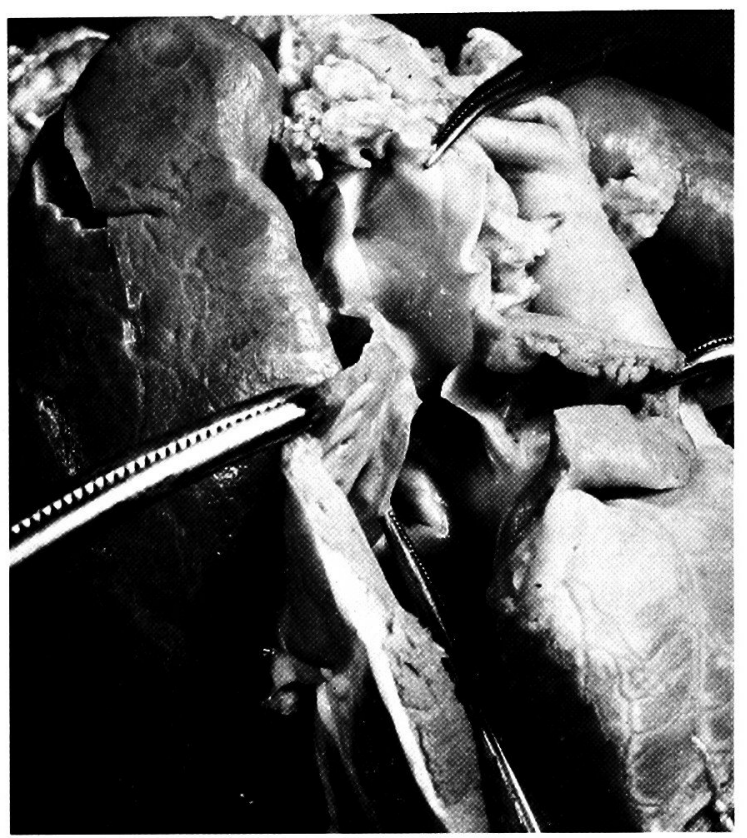

Fig. 6. Anterior view of the right atrium and ventricle. (Case 3)

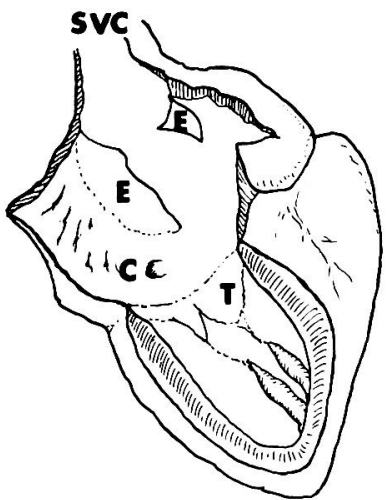

a

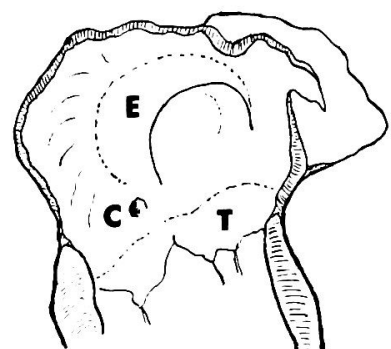

b

Fig 7. The " $a$ " is a diagram of Fig. 6 (Case 3). The " $b$ " is a diagram of the reconstructed interior view of the right atrium. C: coronary sinus. E: Eustachian valve. SVC: Superior vena cava. $\mathrm{T}$ : Tricuspid valve.

\section{Discussion}

During the embryonic development of the heart, the single atrial cavity is divided into two definite chambers in the following manner: the septum primum arises from the mid-dorsal wall of the atrium and progressed downward toward the 
atrioventricular opening. Two swellings appear in the wall of the atrioventricular canal, forming the septum intermedium. The narrow opening between the septum primium and the septum intermedium is the ostium primum. Before the continued growth of the septum primum completely closes the ostium primum, an area of the septum near its cephalic attachment to the atrial wall thins out and breaks through, forming the ostium secundum. In the right atrium, a new partition grows downward from the cephalic and ventral part of the atrial wall as the septum secundum. Its downward growth ceases before it completely covers the new opening of the septum primum, leaving a communication known as the foramen ovale (Henry Gray 1959)

The right atrium of the adult heart is developed from the sinus venosus, the primitive atrium and the right half of the atrial canal. The sinus venosus opens into the dorsal wall of the primitive atrium through the verticaly placed sinoatrial foramen. This slit-like opening is guarded by two valves, the right and left valvulae venosae. Above the opening, the two venous valves unite into a single fold, forming the septum spurium. Below, these valves also fuse and are continued toward the atrial canal (Hickie 1956). The muscular fused portion contracts during atrial systole, thus preventing backflow of atrial blood into the sinus venosus (Lucas and Schmidt 1968). As development progresses, the orifice of the transverse part of the sinus venosus is drawn into the posterior wall of the right atrium, and the left valve and septum spurium fuse with the septum secundum. The upper part of the sinus becomes the opening for the superior vena cava. The inferior part is divided by the further growth of the right venous valve into two openings, the inferior vena cava and the coronary sinus.

Bands of muscle form between the openings of the coronary sinus, the superior and inferior venae cavae, so that the original sinus opening and right sinus valve are divided into three parts: (1) the superior caval opening ridged above and laterally by the remains of the upper part of the right sinus valve-the crista terminalis; (2) the inferior caval opening bounded in front by the middle half of the right venous valve-the Eustachian valve; and (3) the coronary sinus bounded on the right by the anterior and of the right sinus valve-the Thebesian valve (Hickie 1956).

The right horn is absorbed into the right atrium, forming the sinus venarum. The primitive atrium becomes the auricular appendage and the area of the atrium provided with musculi pectinati. The right half of the atrial canal forms the smooth area above the atrioventricular orifice.

In the fetal heart, the free concave cranial border of the Eustachian valve is directed upward and medially, channeling the blood stream from the inferior vena cava through the foramen ovale into the left atrium (Yater 1929).

The adult Eustachian valve is a musculomembranous semilunar fold, attached to the ventral and left margin of the orifice of the inferior vena cava. Its concave free margin ends in two cornua, the left of which is continuous with the ventral margin of the limbus fossae ovalis and the right spreads out on the atrial wall. 


\begin{tabular}{|c|c|c|c|c|}
\hline Author & Year & Age & Sex & Clinical data \\
\hline Lindes & 1865 & $4 \mathrm{hrs}$ & M & $\begin{array}{l}\text { Born during eighth month of } \\
\text { gestation } \\
\text { Ascites noted at birth }\end{array}$ \\
\hline Maier & 1867 & 33 yrs & $\mathrm{F}$ & Chronic bronchitis \\
\hline Von Rokitansky & 1875 & & & \\
\hline $\begin{array}{l}\text { Lauenstein } \\
\text { (5 cases) }\end{array}$ & 1876 & & & Two female and three male patients \\
\hline $\begin{array}{l}\text { Moore (also } \\
\text { mentions two } \\
\text { similar cases) }\end{array}$ & 1883 & 33 yrs & $\mathrm{F}$ & Tuberculosis \\
\hline Leo & 1886 & 2 yrs & $\mathbf{F}$ & Intense cyanosis since birth \\
\hline Preisz & 1890 & Stillbirth & $\mathbf{M}$ & \\
\hline Stadler & 1890 & $3 \mathrm{mo}$ & $\mathbf{F}$ & \\
\hline Przewoski & 1897 & & & \\
\hline Chiari & 1897 & $24 \mathrm{yrs}$ & $\mathbf{M}$ & $\begin{array}{l}\text { Pulmonary embolism from thrombus } \\
\text { in network }\end{array}$ \\
\hline Chiari & 1897 & $43 \mathrm{yrs}$ & M & Chronic disseminated tuberculosis \\
\hline Chiari & 1897 & $30 \mathrm{yrs}$ & $\mathbf{M}$ & Aortic valvular endocarditis \\
\hline Chiari & 1897 & 45 yrs & $\mathrm{F}$ & Chronic pulmonary tuberculosis \\
\hline
\end{tabular}




\begin{tabular}{|c|c|c|}
\hline Cause of death & Eustachian valve anomaly & Associated cardiac defects \\
\hline & $\begin{array}{l}\text { Persistent right and left venous } \\
\text { valves }\end{array}$ & $\begin{array}{l}\text { Single atrial cavity } \\
\text { Common atrioventricular canal } \\
\text { Stenosis of pulmonary valve } \\
\text { Patent ductus arteriosus } \\
\text { Persistent left SVC }\end{array}$ \\
\hline \multirow[t]{3}{*}{$\begin{array}{l}\text { "Hydrothorax" } \\
\text { "Hydropericardium" } \\
\text { "Hydrops Ascites" }\end{array}$} & $\begin{array}{l}\text { Two folds in right atrium } \\
\text { representing persistent right } \\
\text { venous valve and remnant } \\
\text { of septum primum }\end{array}$ & \multirow[t]{2}{*}{$\begin{array}{l}\text { Dilatation and hypertrophy of } \\
\text { right atrium and ventricle } \\
\text { Mitral stenosis } \\
\text { Left atrial dilatation } \\
\text { Hypoplastic left ventricle }\end{array}$} \\
\hline & Persistent right venous valve & \\
\hline & $\begin{array}{l}\text { Eustachian and Thebesian valves } \\
\text { formed by one extensive membrane } \\
\text { Simple membrane in one case, } \\
\text { fenestrated membrane in three } \\
\text { cases, network of fine fibers in } \\
\text { fifth case }\end{array}$ & $\begin{array}{l}\text { Patent foramen ovale in one } \\
\text { case }\end{array}$ \\
\hline Tuberculosis & $\begin{array}{l}\text { Large muscular fold beginning } \\
\text { below fossa ovalis and stretching } \\
\text { from interatrial septum near } \\
\text { of right atrium, representing } \\
\text { exagerated Eustachian valve with } \\
\text { excessive development of inferior } \\
\text { sinus septum }\end{array}$ & \\
\hline \multirow{2}{*}{$-\ldots-\cdots$} & $\begin{array}{l}\text { Sail-like Eustachian valve with } \\
\text { several perforations }\end{array}$ & $\begin{array}{l}\text { Absence of tricuspid valve } \\
\text { Atresia of pulmonic valve } \\
\text { Hypoplasia of right ventricle } \\
\text { Patent foramen ovale } \\
\text { Patent ductus arteriosus }\end{array}$ \\
\hline & $\begin{array}{l}\text { Sieve-like flap at right border of } \\
\text { IVC and coronary sinus corres- } \\
\text { ponding to right venous valve }\end{array}$ & \multirow[b]{2}{*}{$\begin{array}{l}\text { Stenotic bicuspid pulmonic valve } \\
\text { Ventricular septal defect } \\
\text { Two pulmonary vein orifices in } \\
\text { left atrium } \\
\text { (Cheilognathopalato-schisis) }\end{array}$} \\
\hline \multirow{2}{*}{ 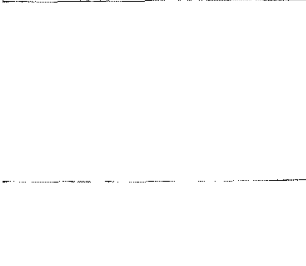 } & $\begin{array}{l}\text { Fold arising from IVC representing } \\
\text { remnant of right venous valve }\end{array}$ & \\
\hline & $\begin{array}{l}\text { Chiari's network containing } \\
\text { thrombus }\end{array}$ & \\
\hline Pulmonary embolism & Chiari's network & \\
\hline Tuberculosis & Chiari's network & Aortic valvular endocarditis \\
\hline $\begin{array}{l}\text { Aortic valvular } \\
\text { endocarditis }\end{array}$ & Chiari's network & \\
\hline Tuberculosis & Chiari's network & Mitral valve stenosis \\
\hline
\end{tabular}




\begin{tabular}{|c|c|c|c|c|}
\hline Author & Year & Age & Sex & Clinical data \\
\hline Chiari & 1897 & 43 yrs & $\mathbf{F}$ & Cardiac disease \\
\hline Chiari & 1897 & 40 yrs & $\mathbf{F}$ & Chronic disseminated tuberculosis \\
\hline Chiari & 1897 & & & Museum preparation \\
\hline Chiari & 1897 & $35 \mathrm{yrs}$ & $\mathbf{F}$ & Cardiac disease \\
\hline Chiari & 1897 & $17 \mathrm{~d}$ & M & Acute "Enterokatarrh" \\
\hline Chiari & 1897 & 30 yrs & M & Chronie pulmonary tuberculosis \\
\hline Chiari & 1897 & $30 \mathrm{yrs}$ & $\mathbf{M}$ & \\
\hline A. Weber & 1898 & & & \\
\hline LeCount & 1901 & & & \\
\hline Looser & 1902 & & & $\begin{array}{l}\text { Thrombi in both femoral veins } \\
\text { Hemorrhagic embolic infarct in left } \\
\text { lung }\end{array}$ \\
\hline Ebbinghaus & 1904 & $52 \mathrm{yrs}$ & $\mathbf{F}$ & $\begin{array}{l}\text { Frequent epistaxes } \\
\text { Apoplexies at ages } 38 \text { and } 40 \text { with } \\
\text { righ hemiplegia }\end{array}$ \\
\hline Wortmann & 1909 & $12 \mathrm{~d}$ & $\mathbf{M}$ & \\
\hline Thilo (5 cases) & 1909 & & & \\
\hline Von Moellendorff & 1912 & & & \\
\hline
\end{tabular}




\begin{tabular}{|c|c|c|}
\hline Cause of death & Eustachian valve anomaly & Associated cardiac defects \\
\hline & & $\begin{array}{l}\text { Left atrial dilatation } \\
\text { Hypertrophy and dilatation of } \\
\text { right atrium and ventricle }\end{array}$ \\
\hline Cardiac failure & Chiari's network & \\
\hline \multirow[t]{2}{*}{ Tuberculosis } & Chiari's network & 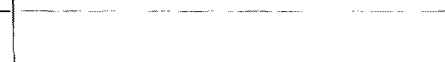 \\
\hline & Chiari's network & \multirow[b]{2}{*}{$\begin{array}{l}\text { Tricuspid valvular endocarditis } \\
\text { Hypertrophy of right ventricle } \\
\text { Mitral valvular stenosis }\end{array}$} \\
\hline Cardiac failure & Chiari's network & \\
\hline Same & Chiari's network & \\
\hline Same & Chiari's network & Patent foramen ovale \\
\hline \multirow[t]{4}{*}{ Cardiac failure } & Chiari's network & $\begin{array}{l}\text { Mitral valvular endocarditis } \\
\text { with stenosis } \\
\text { Aortic valvular endocarditis } \\
\text { with insufficiency }\end{array}$ \\
\hline & $\begin{array}{l}\text { Chiari's network derived from } \\
\text { right venous valve and inferior } \\
\text { sinus septum, with smaller } \\
\text { network representing remanns of } \\
\text { left venous valve }\end{array}$ & \multirow[b]{3}{*}{ (1) } \\
\hline & $\begin{array}{l}\text { Chiari's network entirely below } \\
\text { orifice of inferior vena cave }\end{array}$ & \\
\hline & $\begin{array}{l}\text { Chiari's network containing } \\
\text { thrombus, considered remnants of } \\
\text { right venous valve, left venous } \\
\text { valve, septum spurium and sinus } \\
\text { septum }\end{array}$ & \\
\hline \multirow[t]{2}{*}{$\begin{array}{l}\text { Hemorrhage into } \\
\text { right basal ganglia } \\
\text { of brain }\end{array}$} & Chiari's network & $\begin{array}{l}\text { Membranous interatrial septum } \\
\text { with eleven foramina } \\
\text { Persistent ostium primum } \\
\text { Persistent ostium secundum } \\
\text { Hypertrophy of right ventricle }\end{array}$ \\
\hline & $\begin{array}{l}\text { Bulging, sac-like membrane } \\
\text { containing thrombus considered } \\
\text { residuum of right venous valve, } \\
\text { with an independent network } \\
\text { along orifice of IVC representing } \\
\text { remnant of left venous valve }\end{array}$ & $\begin{array}{l}\text { Tricuspid stenosis } \\
\text { Stenotic right ventricular } \\
\text { outflow tract } \\
\text { Transposition of great vessels }\end{array}$ \\
\hline \multirow{2}{*}{$-\ldots-\cdots-\cdots$} & $\begin{array}{l}\text { Reticula resembling Chiari's } \\
\text { networks in right atrium. One case } \\
\text { contains thrombus in network }\end{array}$ & \\
\hline & $\begin{array}{l}\text { Remnants of both right and left } \\
\text { venous valves present. Sinus } \\
\text { septum had not divided right } \\
\text { venous valve into Eustachian } \\
\text { and Thebesian valves. }\end{array}$ & \\
\hline
\end{tabular}




\begin{tabular}{|c|c|c|c|c|}
\hline Author & Year & Age & Sex & Clinical data \\
\hline Sternberg & 1913 & $21 \mathrm{yrs}$ & F & $\begin{array}{l}\text { Aortic and mitral endocarditis } \\
\text { following tonsillitis }\end{array}$ \\
\hline Haas & 1916 & & & $\begin{array}{l}\text { Thrombus in left femoral vein, } \\
\text { embolus in network }\end{array}$ \\
\hline F.P. Weber & 1920 & $25 \mathrm{yrs}$ & M & $\begin{array}{l}\text { "Sarcomatous tumor" of left kidney, } \\
\text { metastatic }\end{array}$ \\
\hline F.P. Weber & 1920 & $29 \mathrm{yrs}$ & M & $\begin{array}{l}\text { Exertional dyspnea since age } 11 \\
\text { years } \\
\text { Systolic murmur } \\
\text { Pulmonary tuberculosis }\end{array}$ \\
\hline Jordan & 1926 & $65 \mathrm{yrs}$ & M & Carcinoma of prostate \\
\hline Jordan & 1926 & $71 \mathrm{yrs}$ & M & Kidney disease \\
\hline Wurm & 1927 & $3 \mathrm{mo}$. & M & $\begin{array}{l}\text { Race: Anamese } \\
\text { Cyanosis, mild } \\
\text { Multiple episodes of dyspnea and } \\
\text { cyanosis preceding death }\end{array}$ \\
\hline Yater (3 cases) & 1929 & & & \\
\hline Yater ( 2 cases) & 1929 & & & \\
\hline Helwig & 1932 & $67 \mathrm{yrs}$ & $\mathbf{F}$ & Dyspnea and auricular fibrillation \\
\hline Helwig & 1932 & $43 \mathrm{yrs}$ & $\mathbf{F}$ & $\begin{array}{l}\text { Rheumatic fever during childhood } \\
\text { Thrombus in left femoral artery } \rightarrow \mathrm{A}-\mathrm{K} \\
\text { amputation }\end{array}$ \\
\hline Helwig & 1932 & 38 yrs & $\mathrm{F}$ & $\begin{array}{l}\text { Exertional dyspnea } \times 10 \text { yrs } \\
\text { Auricular fibrillation } \\
\text { Right hemiplegia }\end{array}$ \\
\hline Helwig & 1932 & $50 \mathrm{yrs}$ & M & $\begin{array}{l}\text { Pain in left chest and left arm } \times 5 \\
\text { years }\end{array}$ \\
\hline Helwig & 1932 & $21 \mathrm{yrs}$ & M & Spindle cell sarcoma, right thigh \\
\hline Helwig & 1932 & 24 yrs & M & Spongioblastoma of cerebral peduncle \\
\hline Helwig & 1932 & $53 \mathrm{yrs}$ & $\mathrm{F}$ & Anemia and spinal cord degeneration \\
\hline
\end{tabular}




\begin{tabular}{|c|c|c|}
\hline Cause of death & Eustachian valve anomaly & Associated cardiac defects \\
\hline \multirow[t]{2}{*}{ Same } & $\begin{array}{l}\text { Abnormally enlarged Eustachian } \\
\text { valve }\end{array}$ & \multirow[t]{2}{*}{$\begin{array}{l}\text { Patent foramen ovale } \\
\text { Mitral valvular endocarditis } \\
\text { Aortic valvular endocarditis }\end{array}$} \\
\hline & $\begin{array}{l}\text { Three groups of threads froming } \\
\text { a network replacing the Eustachian } \\
\text { and Thebesian valves. Embolus, } \\
6 \mathrm{~cm} \text { long, ensnared by network }\end{array}$ & \\
\hline Same & Chiari's network & \\
\hline Tuberculosis & Chiari's network & $\begin{array}{l}\text { Dilatation and hypertrophy of } \\
\text { right atrium } \\
\text { Thrombus attached to chordae } \\
\text { tendineae of tricuspid valve } \\
\text { Contracted pulmonary orifice } \\
\text { with thickened semilunar } \\
\text { cusps. Adherent thrombi } \\
\text { in pulmonay artery }\end{array}$ \\
\hline Same & Chiari's network & \\
\hline \multirow[t]{4}{*}{ Same } & Chiari's network & \\
\hline & Chiari's network & $\begin{array}{l}\text { Corrected transposition of great } \\
\text { vessels } \\
\text { Coarctation of aorta } \\
\text { Tricuspid insufficiency } \\
\text { Patent foramen ovale }\end{array}$ \\
\hline & Chiari's network & \\
\hline & $\begin{array}{l}\text { Both Eustachian and Thebesian } \\
\text { valves formed of one membrane }\end{array}$ & \\
\hline Cardiac failure & Chiari's network & $\begin{array}{l}\text { Mitral valvular stenosis and } \\
\text { regurgitation } \\
\text { Dilated left atrium (capacity } \\
1000 \mathrm{cc} \text { ) } \\
\text { (Atrophic left lung, diameter } \\
5 \mathrm{~cm} \text { ) }\end{array}$ \\
\hline Cardiac failure & Chiari's network & $\begin{array}{l}\text { Mitral stenosis } \\
\text { Tricuspid stenosis } \\
\text { Bilateral atrial dilatation } \\
\text { Dilated coronary sinus }\end{array}$ \\
\hline Cardiac failure & Chiari's network & Mitral stenosis \\
\hline $\begin{array}{l}\text { Heart failure } \\
\text { Pulmonary edema }\end{array}$ & Chiari's network & $\begin{array}{l}\text { Myocardial infarct, anterior } 2 / 3 \\
\text { of interventricular septum }\end{array}$ \\
\hline Same & Chiari's network & \\
\hline Same & Chiari's network & \\
\hline Same & Chiari's network & \\
\hline
\end{tabular}




\begin{tabular}{|c|c|c|c|c|}
\hline Author & Year & Age & Sex & Clinical data \\
\hline Helwig & 1932 & & & Museum preparation \\
\hline Gomberg & 1933 & $42 \mathrm{yrs}$ & $\mathbf{F}$ & Postpartum pulmonary embolism \\
\hline Kettler & 1934 & 60 yrs & $\mathrm{M}$ & Pulmonary embolism \\
\hline Ruggieri & 1935 & 42 yrs & $\mathrm{F}$ & $\begin{array}{l}\text { Cyanosis, systolic murmur since age } \\
12 \text { years } \\
\text { Syphilis in adult life }\end{array}$ \\
\hline Ponhold & 1937 & $2 d$ & $\mathbf{F}$ & Cyanosis noted on second day of life \\
\hline $\begin{array}{l}\text { Dubin and } \\
\text { Hollinshead }\end{array}$ & 1944 & $5 \mathrm{~min}$ & $\mathbf{F}$ & Race: Negro; Heart failure \\
\hline Kjellberg & 1955 & $6 \mathrm{yrs}$ & M & Pulmonic stenosis \\
\hline Hickie & 1956 & 47 yrs & M & $\begin{array}{l}\text { Progressive exertional dyspnea } \\
\text { Recurrent chest infections } \\
\text { Left precordial pain } \\
\text { Paroxysmal nocturnal dyspnea }\end{array}$ \\
\hline Hickie & 1956 & 27 yas & M & $\begin{array}{l}\text { Progressive dyspnea; recurrent } \\
\text { bronchitis }\end{array}$ \\
\hline $\begin{array}{l}\text { Rossall and } \\
\text { Caldwell }\end{array}$ & 1957 & 19 yrs & M & $\begin{array}{l}\text { Varicose veins, hepatomegaly, } \\
\text { pleural effusions, ascites, jaundice }\end{array}$ \\
\hline
\end{tabular}




\begin{tabular}{|c|c|c|}
\hline Cause of death & Eustachian valve anomaly & Associated cardiac defects \\
\hline & Chiari's network & \\
\hline Same & $\begin{array}{l}\text { Abnormally enlarged Eustachian } \\
\text { valve }\end{array}$ & $\begin{array}{l}\text { Defect of froamen I } \\
\text { Hypoplasia of right ventricle } \\
\text { Small pulmonary trunk }\end{array}$ \\
\hline Same & $\begin{array}{l}\text { Abnormally enlarged Eustachian } \\
\text { valve }\end{array}$ & $\begin{array}{l}\text { Patent foramen ovale } \\
\text { "Wide" pulmonary trunk }\end{array}$ \\
\hline Heart failure & $\begin{array}{l}\text { Abnormally enlarged Eustachian } \\
\text { valve } \\
\text { Microesopic: Eustachian valve } \\
\text { consists of dense connective tissue } \\
\text { containing many thick elastic fibers }\end{array}$ & $\begin{array}{l}\text { Patent foramen ovale } \\
\text { "Narrow" pulmonary trunk }\end{array}$ \\
\hline Heart failure & $\begin{array}{l}\text { Abnormally enlarged Eustachian } \\
\text { valve }\end{array}$ & $\begin{array}{l}\text { Patent foramen ovale } \\
\text { Patent ductus arteriosus } \\
\text { Hypoplasia of tricuspid valve } \\
\text { Hypoplasia of right ventricle } \\
\text { Complete subvalvular pulmonic } \\
\text { atresia } \\
\text { Membranous interventricular } \\
\text { septal defect }\end{array}$ \\
\hline Heart failure & $\begin{array}{l}2 \times 3 \mathrm{~cm} \text { large membranous septum } \\
\text { with few fenestrations at edges, } \\
\text { attached superiorly to crista } \\
\text { terminalis, inferiorly to tricuspid } \\
\text { valve rign } \\
\text { Microscopic: Dense connective } \\
\text { tissue with bundles of elastic } \\
\text { fibers and cardiac muscle. Each } \\
\text { surface of Eustachian valve is } \\
\text { covered by single layer of endo. } \\
\text { thelium }\end{array}$ & $\begin{array}{l}\text { Patent foramen ovale } \\
\text { Patent ductus arteriosus } \\
\text { Bicuspid hypoplastic tricuspid } \\
\text { valve } \\
\text { Hypoplasia of pulmonary trunk }\end{array}$ \\
\hline Heart failure & $\begin{array}{l}\text { Abnormally enlarged Eustachian } \\
\text { valve }\end{array}$ & $\begin{array}{l}\text { Infundibular pulmonic stenosis, } \\
\text { surgically corrected }\end{array}$ \\
\hline $\begin{array}{l}\text { Died on operating } \\
\text { table during atrio- } \\
\text { septopexy }\end{array}$ & $\begin{array}{l}\text { Eustachian valve divides right } \\
\text { atrium into two chambers, the } \\
\text { sinus venarum and the dilated } \\
\text { right auricular appendage. Valve } \\
\text { is perforated, } 6.2 \mathrm{~cm} \text { along free } \\
\text { edge, } 2.1 \mathrm{~cm} \text { wide, } 0.5 \mathrm{~cm} \text { thick, } \\
\text { with Chiari's network arising from } \\
\text { right edge }\end{array}$ & $\begin{array}{l}\text { Patent foramen ovale } \\
\text { Atrial septal defect } \\
\text { Tricuspid valvular insufficiency } \\
\text { Mitral valvular stenosis } \\
\text { Dilated right atrium } \\
\text { Dilatation and hypertrophy of } \\
\text { right ventricle }\end{array}$ \\
\hline $\begin{array}{l}\text { Died postoperatively } \\
\text { following atrio- } \\
\text { septopexy }\end{array}$ & $\begin{array}{l}\text { Muscular Eustachian valve, } 4.7 \mathrm{~cm} \\
\text { along free edge, } 1.5 \mathrm{~cm} \text { wide, } \\
0.7 \mathrm{~cm} \text { thick }\end{array}$ & $\begin{array}{l}\text { Atrial septal defect } \\
\text { Dilatation of right atrium } \\
\text { Dilatation and hypertrophy } \\
\text { of right ventricle } \\
\text { Anomalous pulmonary venous } \\
\text { return, partial, into right SVC } \\
\text { Dilated pulmonary artery }\end{array}$ \\
\hline Cardiac cirrhosis & $\begin{array}{l}\text { Thin fibrous diaphragm-like } \\
\text { Eustachian valve almost completely } \\
\text { obstructing orifice of IVC, } 4.4 \mathrm{~cm} \\
\text { along free border, } 2.6 \mathrm{~cm} \text { in depth. }\end{array}$ & \\
\hline
\end{tabular}




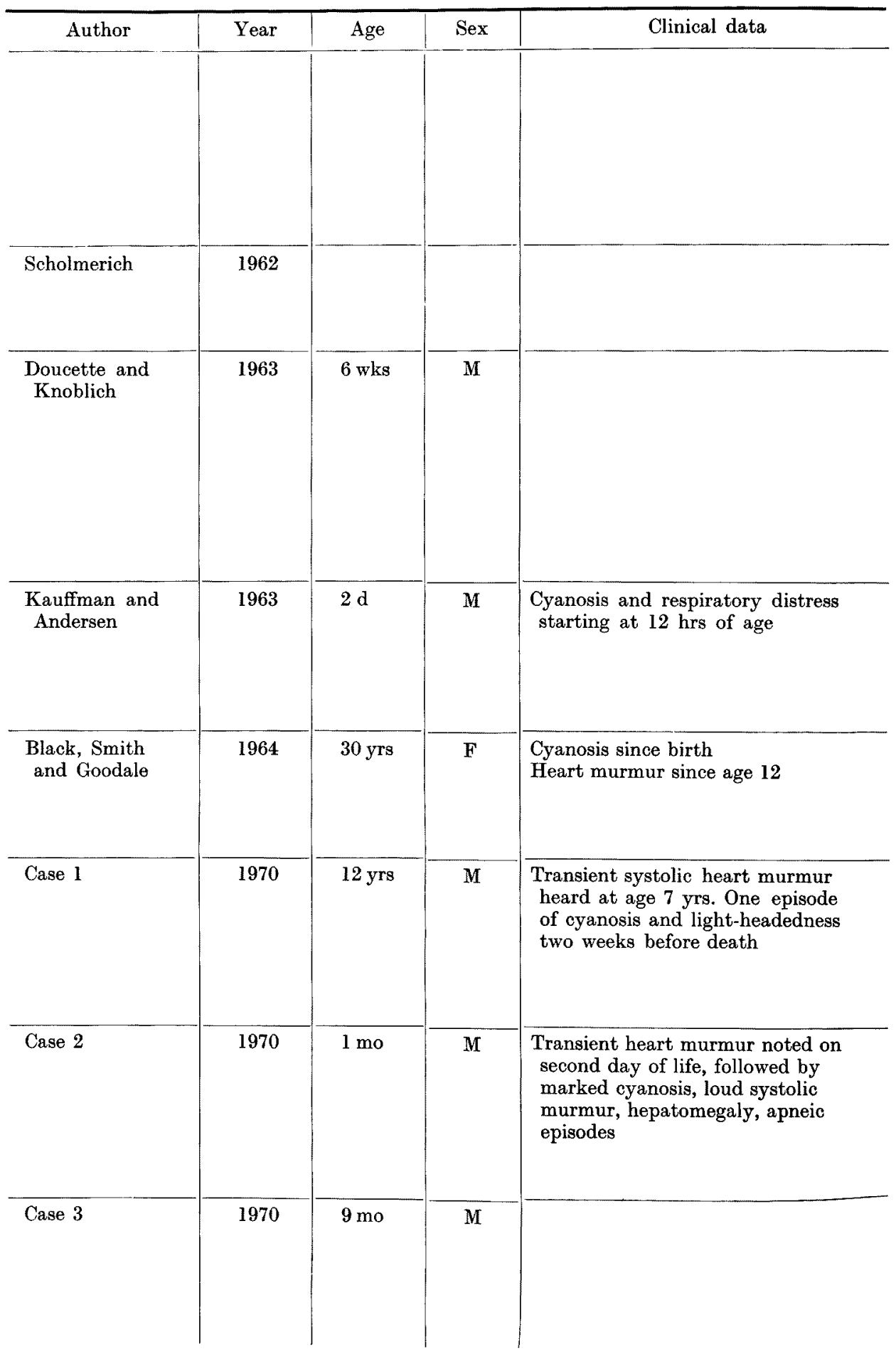




\begin{tabular}{|c|c|c|}
\hline Cause of death & Eustachian valve anomaly & Associated cardiac defects \\
\hline & $\begin{array}{l}\text { Microscopic: Surface lined by single } \\
\text { layer of flattened endothelium, } \\
\text { moderately cellular connective } \\
\text { tissue intermingled with numerous } \\
\text { small elastic fibers. No cardiac } \\
\text { musculature within valve itself. } \\
\text { Small arterioles and dilated venules } \\
\text { present within substance of valve. }\end{array}$ & \\
\hline & $\begin{array}{l}\text { Abnormally enlarged Eustachian } \\
\text { valve excluding IVC and coronary } \\
\text { sinus from right atrium while SVC } \\
\text { drained normally. }\end{array}$ & \\
\hline \multirow[t]{2}{*}{$\begin{array}{l}\text { Postoperative death } \\
\text { following modified } \\
\text { Pott's procedure }\end{array}$} & $\begin{array}{l}\text { Right atrium completely divided by } \\
\text { muscular septum showing three } \\
\text { perforations. It straddled the } \\
\text { medial portion of the tricuspid valve } \\
\text { and lay to the right of the SVC, IVC } \\
\text { and coronary sinus. It separated } \\
\text { atrial appendage from the sinus } \\
\text { the venarum and terminated } \\
\text { ventrocephalad in the right wall } \\
\text { of the SVC. }\end{array}$ & $\begin{array}{l}\text { Patent foramen ovale } \\
\text { Patent ductus arteriosus } \\
\text { Hypoplasia of tricuspid valve } \\
\text { Atresia of pulmonary valve } \\
\text { Hypoplasia of right ventricle }\end{array}$ \\
\hline & Persistent venous valves & $\begin{array}{l}\text { Hypoplasia of tricuspid valve } \\
\text { Pulmonary atresia } \\
\text { Multiple coronary artery- } \\
\text { ventricular communications } \\
\text { Focal necrosis, right ventricular } \\
\text { myocardium }\end{array}$ \\
\hline $\begin{array}{l}\text { Postoperative } \\
\text { infection }\end{array}$ & $\begin{array}{l}\text { Failure of regression of right valve } \\
\text { of sinus venosus, causing tunneling } \\
\text { of IVC between the two leaves } \\
\text { of the atrial septum into left } \\
\text { atrium }\end{array}$ & $\begin{array}{l}\text { (Multiple pulmonary arterio- } \\
\text { venous fistulae) }\end{array}$ \\
\hline $\begin{array}{l}\text { Sudden death during } \\
\text { exercise }\end{array}$ & $\begin{array}{l}\text { Semilunar Eustachain valve, } 2.4 \mathrm{~cm} \\
\text { at margin, } 2.1 \mathrm{~cm} \text { in width and } \\
2 \mathrm{~mm} \text { in thickness, constricting } \\
\text { IVC orifice. Microscopic: Normal } \\
\text { cardiac muscle bundles continuous } \\
\text { with musculature of right atrial } \\
\text { wall }\end{array}$ & $\begin{array}{l}\text { Left ventricular hypertrophy } \\
\text { Microscopic appearance of } \\
\text { severe chronic myocarditis } \\
\text { in sections from left ventricle }\end{array}$ \\
\hline Cardiac failure & $\begin{array}{l}\text { Thin, membranous, abnormally } \\
\text { elongated Eustachian valve } \\
\text { exhibiting an area of aneurysmal } \\
\text { dilatation in its mid-portion }\end{array}$ & $\begin{array}{l}\text { Dilatation and hypertrophy } \\
\text { of right ventricle } \\
\text { Patent foramen ovale } \\
\text { Interventricular septal defect } \\
\text { Right-sided aortic arch } \\
\text { Hemangioma, septal cusp of } \\
\text { tricuspid valve }\end{array}$ \\
\hline $\begin{array}{l}\text { Thromboembolism in } \\
\text { left internal carotid } \\
\text { artery }\end{array}$ & $\begin{array}{l}\text { Thin, membranous, abnormally } \\
\text { enlarged Eustachian valve, } 11 \mathrm{~mm} \\
\text { at greatest width }\end{array}$ & $\begin{array}{l}\text { Dilatation and hypertrophy of } \\
\text { right ventricle } \\
\text { Patent foramen ovale } \\
\text { Interventricular septal defect } \\
\text { Transposition of great vessels } \\
\text { Patent ductus arteriosus }\end{array}$ \\
\hline
\end{tabular}


Its adherent border is a transverse muscular ridge continuous with the anterior margin of the inferior caval orifice (Henry Gray 1959). One of its surfaces is turned laterally toward the atrium and the other medially toward the inferior vena cava. The valve in the adult is usually rudimetary and has little, if any, functional significance. It is variable in size with an average length at its free edge of $3.4 \mathrm{~cm}$ and average width of $0.35 \mathrm{~cm}$. It may be a single fold or fenestrated or may consist of a network of threads or even be entirely absent (Yater 1929).

In the animal kingdom, the venous valves may persist partly or entirely, as shown by Born (1888) in mammals and by Rose (1890) in monotremes and maruspials. Weber (1904) quoted Grosser as having found a persistence of the left venous valve in a certain number of Cheiroptera, and Devez in the American Didelphys. The Echidna (monotreme) has a valve for each vena cava and a valve common to both. The Ornithorynchus has a common internal valve represented by a simple musculomembranous ridge. Other animals having an internal valve in the inferior vena cava are the Myrmecopha tetradactyla, the jaguar and the cabai.

In man, the Eustachian valve was first described in 1563 by Bartolomeno Eustachius (1563). Its existence was denied by Bauhin in 1605 . Harvey, in his work (Exercitatio Anatomica de Motu Cordis et Sanguinis in Animalbus published in 1628), does not mention the Eustachian valve. Winslow gave the first accurate description in 1717, and was also the first person to suggest its fetal function. Sabatier (1774) and Barclay et al. (1944) later established that the valve directed blood across the foramen ovale into the left atrium in fetal life.

Anomalies of the Eustachian valve consist of variations in size, extent, muscularity, and formation of Chiari's network (Lindes 1865, Maier 1867, Von Rokitansky 1875, Lauenstein 1876, Moore 1883, Leo 1886, Preisz 1890, Stadler 1890, Przewoski 1896, Chiari 1897, Le Count 1901, Loose 1902, Ebbinghaus 1904, Thilo 1909, Wormann 1909, Von Moellendorff 1912, Sternberg 1913, Haas 1916, Weber 1920, Jordan 1926, Wurm 1927, Yater 1929, Helwig 1932, Gomberg 1933, Kettler 1934, Ruggieri 1935, Ponhold 1937, Dubin and Hollinshead 1944, Gross et al. 1953, Kjellberg 1955, Hickie 1956, Rossall and Caldwell 1957, Scholmerich et al. 1962, Doucette and Knoblich 1963, Kauffman and Andersen 1963, Black et al. 1964, Lucas and Schmidt 1968).

\section{Classifications}

Minor abnormal persistence of the valves of the sinus venosus, resulting in larger than usual Eustachian valves, were reviewed and classified by Yatar in 1929. In his study comprising 120 adult hearts, all the Eustachian valves conformed to one or another of six anatomic types. A brief description of each type follows:

1) Absence of Eustachian valve (17 cases). The sinus septum and anterior rim of the inferior vena cava were all that denoted the previous existence of the right venous valve, except for the Thebesian valve, which was present in 16 cases 
and absent in one case.

2) The Eustachian valve present as a simple non-fenestrated flap or membrane (69 cases). The usual form was crescentic. It varied from a narrow little fold along the anterior edge of the orifice of the inferior vena cava, to a broad membrane $2.3 \mathrm{~cm}$ wide. The valve in some cases was a thin, Habby, transparent membrane distinct from the rim of the inferior vena cava. In others, it was a taut fold merging with the rim of the inferior vena cava and the wall of the right atrium. It sometimes contained muscle fibers, especially near the attached edge.

3) The Eustachian valve present as a fenestrated semilunar membrane (22 cases).

4) The Eustachian valve formed in part or completely of a network of threads (7 cases).

5) Both the Eustachian and Thebesian valves formed of a single membrane ( 2 cases).

6) Chiari's network (3 cases). Usually Chiari's networks are persistent right valves and extend from the crista terminalis or tuberculum Loweri to the Eustachian and/or Thebesian valves.

In these cases of Yater (1929), the average width was $0.35 \mathrm{~cm}$ and the average length at the free edge was $3.42 \mathrm{~cm}$. The minimal width was $0.15 \mathrm{~cm}$ and maximal width $2.3 \mathrm{~cm}$. The minimal length at the free edge was $1.7 \mathrm{~cm}$ and maximal length $7.5 \mathrm{~cm}$.

The lesions previously described represent minor abnormal variation or persistence of the right venous valve of the sinus venosus which are usually of little or no hemodynamic consequence. Pathologic persistence of the right valve of the sinus venosus, producing subdivision of the right atrium and on rare occasions causing obstruction to systemic venous return, is an uncommon condition. In addition to our cases, we have been able to trace in the literature only 70 other cases.

Six anatomic patterns are recognized by Lucas and Schmidt (1968):

1) In the complete form, the right atrium is divided into two chambers, the sinus venarum and the right atrium proper, by a membranous right valve which extends from the crista terminalis laterally to the medial wall, and from the superior vena cava above to a point below the coronary sinus. The sinus venarum receives the inferior vena cava, the superior vena cava and the coronary sinus. The true right atrium has the right auricular appendage and communicates with the right ventricle by way of the tricupsid valve. Variable-sized defects in the abnormal valve allow communications between the sinus venarum and the true right atrium. The foramen ovale also allows communication from the sinus venarum to the left atrium.

2) The superior and inferior venae cavae empty into the sinus venarum while the coronary sinus empties normally into the right atrium proper.

3) Only the inferior vena cava is within the sinus venarum. The superior 
vena cava and the coronary sinus drain normally into the true right atrium. The persistent valve fuses with the septum secundum at the foramen ovale and blood from the inferior vena cava drains through this opening into the left atrium.

4) Only the ostium of the coronary sinus is excluded. The superior and inferior venae cavae drain into the true right atrium.

5) The inferior vena cava and the coronary sinus are both excluded from the right atrium while the superior vena cava drains normally.

6) The persistent right valve is not within the right atrium but at the junction of the inferior vena cava and the right atrium, causing partial or complete obstruction of the inferior vena cava.

The first patient presented in this report has an Eustachian valve anomaly which appears to belong to the third anatomic pattern listed above.

Most of the cases previously reported exhibited some form of associated right heart anomaly, usually in the form of pulmonary atresia, hypoplastic tricuspid valve and right ventricle. Significant inferior vena cava obstruction has been previously reported in only one patient (Rossall and Caldwell 1957). In our case, it was most likely responsible for his sudden demise. This obstruction to systemic venous return, evidenced by marked degree of congestion of the neck veins, liver, spleen, kidneys and other intraabdominal organs, was of acute nature. The young adult reported by Rossall and Caldwell (1957) had chronic obstruction and had as a consequence developed collateral venous pathways and centrolobular necrosis of the liver prior to his eventual demise.

The second patient presents, among other congenital defects, an abnormality of the Eustachian valve which had been previously reported on only one occasion by Wortmann (1909), in an infant with a bulging, sac-like membrane containing a thrombus in place of an Eustachian valve. This particular aneurysm, present in our second patient, was probably of no hemodynamic importance. The associated interventricular septal defect was undoubtedly the primary factor causing heart failure and death. This abnormal valve again separated the inferior vena cava from the superior vena cava and the coronary sinus and would belong to the third anatomic pattern in the classification of Lucas and Schmidt (1968).

The third patient had, among numerous other congenital cardiac defects, an abnormally enlarged Eustachian valve. The right atrium was partitioned into the sinus venarum containing the inferior vena cava entrance, and the right atrium proper, containing the orifices of the superior vena cava and the coronary sinus. Again, such an arrangement falls into the third anatomic type in the classification of Lucas and Schmidt (1968). As in the second case, the Eustachian valve anomaly is not believed to have been hemodynamically significant.

In view of the rapidly increasing number of intracardiac operations performed nowadays, the authors wish to emphasize the importance to be aware of the structural anomaly of the Eustachian valve. It can be a surgically correctable cause of heart failure. It can also confuse the surgeon who tries to manually delineate the anatomy of the right atrium, as happened in the two cases 
reported by Hickie (1956).

\section{SUMmaRY}

Three cases of congenital cardiac anomalies involving the Eustachian valve are presented. The first is a case of a 12-year-old boy with findings of severe chronic myocarditis combined with an anomalous Eustachian valve which divided the right atrium and caused moderate constriction of the inferior veana cava orifice, resulting in marked congestion of the intraabdominal viscera. The second case, a 30-day-old male infant, exhibited an area of aneurysmal dilatation in the midportion of the Eustachian valve associated with interventricular septal defect and right aortic arch. The third case, a 9-month-old male child with interventricular septal defect, transposition of the great vessels, bicuspid pulmonic valve and anomalous origin of the left subclavian artery, had an abnomrally enlarged, membranous Eustachian valve. A review of similar anomalies reported in the literature and of the classification of minor variations and major anomalies is presented.

\section{Acknowledgment}

We wish to express our gratitude to Dr. Kornel L. Terplan for his suggestions in the preparation of this paper, and to Mr. T. Llyle Keith for his technical assistance.

\section{References}

1) Bailey, C.P., Bolton, H.E., Jamison, W.L. \& Neptune, W.B. Atrio-septo-pexy for interatrial septal defects. J. thorac. Surg., 1953, 26, 184-219.

2) Barclay, A., Franklin, J. \& Prichard, M. The Foetal Circulation, Blackwell, London, 1944.

3) Bauhin, C. Theatrum anatomica. (1605) (cited by Hickie in 18).

4) Bjork, V.O., Crafoord, C., Jonsson, B., Kjellberg, S.R. \& Rudhe, U. Atrial septal defects. Acta. chir. scand., 1954, 107, 499-515.

5) Born, G. Üeber der Bildung der Klappen, Ostien und Schweidewaende im Saeugetierherzen. Anat. Anz., 1888, 3, 606-612.

6) Black, H., Smith, G.T. \& Goodale, W.T. Anomalous inferior vena cava draining into the left atrium associated with intact interatrial septum and multiple pulmonary arteriovenous fistulae. Circulation, 1964, 29, 258-267.

7) Chiari, H. Üeber Netzbildungen im rechten Vorhofe des Herzens. Beitr. path. Anat. 1897, 22, 1-10.

8) Doucette, J. \& Knoblich, R. Persistent right valve of the sinus venosus. Arch. Path., $1963,75,105-112$.

9) Dubin, I.N. \& Hollinshead, W.H. Congenitally insufficient tricuspid valve accompanied by an anomalous septum in the right atrium. Arch. Path., 1944, 38, 225-228.

10) Ebbinghaus, H. Zur Kasuistik der kongenitalen Herzfehler und deren möglichen Folgen. Münch. med. Wschr., 1904, 51, 797. (cited by Yater in 49).

11) Eustachius, B. Opuscula. Anatomica, 1563 (cited by Hickie in 18).

12) Gomberg, H. Beiträge zur Pathologie der Vorhofsschiedewand des Herzens. Beitr. Path. Anat., 1933, 91, 483-502.

13) Gross, R.E., Watkins, E., Jr., Pomeranz, A.A. \& Goldsmith, E.I. A method for surgical closure of interauricular septal defects. Surg. Gynec. Obstet., 1953, 96, $1-23$. 
14) Haas, W. Üeber einen weiteren Fall von Netzbildungen im rechten Vorhof mit einem in denselben verfangenen Embolus. Inaug. Dis. Karlsruhe. 1916 (cited by Yater in 49).

15) Harvey, W. Exercitatio Anatomica de Motu Cordis et Sanguinis in Animalibus. (1628) (cited by Hickie in 18).

16) Helwig, F.C. The frequency of anomalous reticula in the right atrium of the human heart "Chiari network": report of 8 cases. Amer. J. Path., 1932, 8, 73-79.

17) Henry Gray, F.R.S. Anatomy of the Human Body. 27th edition. Lea \& Febiger, Philadelphia, 1959, pp. 567-601.

18) Hickie, J.B. The valve of the inferior vena cava. Brit. Heart J., 1956, 18, 320-326.

19) Jordan, W.R. Two cases of Chiari's network. Arch. Path., 1926, 2, 840-843.

20) Kauffman, S.L. \& Andersen, D.H. Persistent venous valves, maldevelopment of the right heart, and coronary artery-ventricular communications. Amer. Heart $J ., 1963$, 66, 664-669.

21) Kettler, L. Eine seltene, praktisch bedeutsame Vorhofmissbildung. Z. Kreisl.-Forsch., $1934,26,649-659$.

22) Kjellberg, S.R. Diagnosis of Congenital Heart Disease, translated by Erica Odelbert, Chicago, The Year Book Medical Publishers, Ine., 1955, p. 25.

23) Lauenstein, C. Varietät der Klappen des rechten Atriums. Virchows Arch. path. Anat., 1876, 68, 632-633.

24) Le Count, E.R. Network Formations in the right auricle, with demonstration of a specimen. Trans. Chic. pxth. Soc., 1901-1903, 5, 309-213.

25) Leo, H. Úeber einen Fall von Entwicklungshemmung des Herzens. Virchows Arch. path. Anat., 1886, 103, 503-515.

26) Lindes, G. Ein Beitrag zur Entwicklungsgeschichte des Herzens, Inaug. Dis., Doprat. 1865 (cited by Yater in 49 ).

27) Looser, E. Ueber die Netzbildungen im rechten Vorhofe des Herzens. Inaug. Dis. Zürich. 1902 (cited by Yater in 49 and von Moellendorff in 42).

28) Lucas, R.V., Jr. \& Schmidt, R.E. Heart Disease in Infants, Children and Adolescents. Edited by A.J. Moss \& F.H. Adams. The Williams \& Wilkins Co., Baltimore, 1968, pp. $672-727$.

29) Maier, R. Zur Casiustik der Herzfehler. Ber. Verh. nat. Ges., 1867, 4, 478 (cited by Yater in 49 ).

30) Moore, N. Variety in the Structure of the Heart, Trans. path. Soc., Lond., 1883, 34, 31-32.

31) Ponhold, J. Ein Cor triatriatum biventriculare. Frankfurt. Z. Path., 1937, 51, 237241.

32) Preisz, H. Beiträge zur Lehre von den angeborenen Herzanomalien., Beitr. path. Anat., 1890, 7, 245-296.

33) Przewoski, E. Anomalae chordae cordis humani; valvule venae cavae superioris. Pam. Towarz. Lek. Warszaw, 1896, 92, 400 (cited by Yater in 49).

34) Röse, C. Beiträge zur vergleichenden Anatomie des Herzens der Wirbelthiere. Morphol. Jahrb., 1890, 16, 27 (cited by Yater in 49).

35) Rossall, R.E. \& Caldwell, R.A. Obstruction of inferior vena cava by a persistent Eustachian valve in a young adult. J. clin. Path., 1957, 10, 40-45.

36) Ruggieri, A. Üeber eine ausgedehnte Diaphragmabildung im rechten Herzvorhof. Zbl. allg. Path., 1935, 63, 129-133.

37) Sabatier. Mém. Acad. Roy. Sci. Paris, 198. (1774) (cited by Hickie in 18).

38) Scholmerich, P., Stein, E., Klinner, W. \& Zenker, R. Transposition der unteren Hohlvene mit Zyanose und Linskhypertrophie. Verh. dtsch. Ges. Kreisl.-Forsch., $1962,28,321$.

39) Stadler, O. Üeber eine seltene Missbildung des Herzens. Verh. phys.-med. Ges., 1890-1891, 24, 61 (cited by Yater in 49).

40) Sternberg, C. Beiträge zur Herzpathologie. Verh. dtsch. path. Ges., 1913, 16, 253262. 
41) Thilo, L. Zur Kenntnis der Missbildungen des Herzens. Inaug. Dis. Leipzig. 1909 (cited by Yater in 49 ).

42) Von Moellendorff, W. Üeber abnorme Erhaltung der Sinusklappen im rechten Vorhof eines menschilichen Herzens. Anat. Anz., 1912, 40, 406-409.

43) Von Rokitansky. Die Defecte der Scheidewände des Herzens. Vienna, 1875 (cited by Yater in 49).

44) Weber, F.P. Interesting cases in which a so-called Chiari's net was found in the right auricle of the heart, with or without the presence of any other congenital cardiac abnormality. Intern. Clin., 1920, 3, 43-51.

45) Weber, A. Restes de la valvule veineuse gauche dans le coeur humain adulte. Bibliog. anat., 1904, 13, 11 (cited by Yater in 49).

46) Winslow, J.B. Mém. Acad. roy. Sci. Paris, 211. (1717) (cited by Hickie in 18).

47) Wortmann, W. Úeber eine seltene Herzmissbildung. Zugleich ein Beitrag zur Frage der Netzbildungen im rechten Vorhofe. Inaug. Dis. Wurzburg., 1909 (cited by Yater in 49).

48) Wurm, H. Angeborener Herzfehler mit "korrigierter" Transposition der grossen Gefaesse. Virchows Arch. path. Anat., 1927, 263, 123-141.

49) Yater, W.M. Variations and anomalies of the venous valves of the right atrium of the human heart. Arch. Path., 1929, 7, 418-441. 